\title{
Alaskan wild food harvester information needs and climate adaptation strategies
}

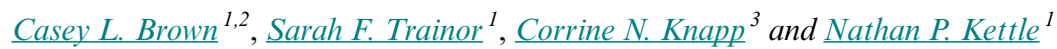

\begin{abstract}
Changing biophysical conditions due to amplified climate change in northern latitudes has significant implications for species' habitat and populations and can dramatically alter interactions between harvesters and local resources. Tribal, regional, and state governments, federal agencies, and other local planning entities have begun documenting observations of changing harvest conditions and the information necessary for communities to adapt to shifting resource availability. We identify and evaluate what stakeholders are saying about wild foods in the context of climate change information needs in Alaska through a review of published grey literature $(\mathrm{n}=87)$. Documents consistently expressed that climate change was impacting habitat conditions, resource distribution, and the abundance of wild foods. They solicited more information on biophysical processes (e.g., sea ice conditions) and populationlevel responses (e.g., shift in migration patterns). They also recommended that future projects focus on information that will improve food security, travel access, and community well-being. Documents suggested that communities have successfully sustained harvest practices, but most current adaptations are localized decisions being made by harvesters to manage the risks of current climate change. Strategies include finding new areas to hunt, substituting harvest species with other wild foods, or using new modes of travel. Documents also identified several adaptation strategies that still need to be implemented, and are dependent on actions by actors at larger scales; these strategies include legal, policy, and management actions to help reduce climate change impacts to wild food harvest. This review of the grey literature complements the climate-change literature by describing information needs of Alaskan wild food harvesters as well as providing tangible suggestions about how to improve adaptation and management strategies for harvesters grappling with changing resource conditions in the Arctic.
\end{abstract}

Key Words: adaptive capacity; Alaska; Arctic; cultural services; needs assessment; subsistence; wild foods

\section{INTRODUCTION}

Wild food harvest, e.g., hunting, fishing, and gathering, supports the livelihoods of numerous rural northern communities around the world. For many residents in Arctic communities, harvesting and consuming wild foods are cultural necessities and essential for health and well-being (Van Daele et al. 2001, Stafford Smith et al. 2011, Loring and Gerlach 2015). However, the practice of harvesting wild foods is increasingly under threat from shifts in weather extremes and long-term climate change (Lynn et al. 2014). Alaska has warmed at approximately twice the global rate affecting a host of processes including redistributions of plant species (Pearson et al. 2013), degrading permafrost (Jorgenson et al. 2010, Liljedahl et al. 2016), earlier snowmelt and later freezeup (Euskirchen et al. 2010), changing seasonality and extent of river and sea ice (Brown et al. 2018), wetland drying (Chen et al. 2018), and increasing wildfire frequency and severity (Kasischke et al. 2010). Implications from changing biophysical conditions are striking for wildlife habitat and populations, and can dramatically alter interactions between harvesters and local resources (Huntington et al. 2016). Changes to distribution and abundance of resources can impact availability, access, and procurement of wild foods (Brinkman et al. 2013, Loring and Gerlach 2015). Because wild foods are commonly shared throughout indigenous communities, these resources concurrently influence many individuals at once, and declining availability could result in a much broader cumulative impact on food security and culture (Ford 2009).

Alaska and the Arctic northern latitudes are widely regarded as a sentinel of global climate change (Hinzman et al. 2005), resulting in a rapid proliferation of research. The explosion of new information has made it challenging for rural residents and decision makers to track existing projects, understand their cumulative insights, and gauge remaining information needs (Ford and Pearce 2012). The scientific emphasis on generating more and better information also shifts the focus away from partnering with user groups to generate research that meets their needs, which often involves utilizing knowledge to better adapt to changing conditions (Tribbia and Moser 2008, Knapp and Trainor 2013). It has become increasingly important to incorporate user needs into research design and communitybased research frameworks for communities seeking to adapt to potential climate risks (Miller and Wyborn 2020). Tribal, regional, and state governments, federal agencies, and other local planning entities have suggested how scientific practices should change to make research more applicable for Alaskans including a process that is transparent, builds networks for knowledge sharing, and creates place-based long-term partnerships with communities (Knapp and Trainor 2013, 2015). Consequently, any process to identify climate change research needs would benefit from drawing from local information needs in their research design.

As residents in northern communities are identifying what they need to know to help them adapt harvest practices to climate change, they are also formalizing strategies to prepare for the physical and socioeconomic impacts (Ford and Pearce 2012, Wotkyns and González-Maddux 2014, Kettle et al. 2017). These preparatory measures include more training, requests for technical assistance, applications for funding to support mitigation and adaptation efforts, and formalized climate adaptation plans (Meeker and Kettle 2017). Rural and indigenous communities have relied on mobility, flexible hunting and harvesting seasons, detailed local and traditional knowledge, and

${ }^{1}$ International Arctic Research Center, University of Alaska Fairbanks, Fairbanks, AK, USA, ${ }^{2}$ Oregon Department of Fish and Wildlife, La Grande, OR, USA, ${ }^{3} \mathrm{Haub}$ School of Environment and Natural Resources, University of Wyoming, Laramie, WY, USA 
Fig. 1. Graphical representation of the document coding and analysis approach.

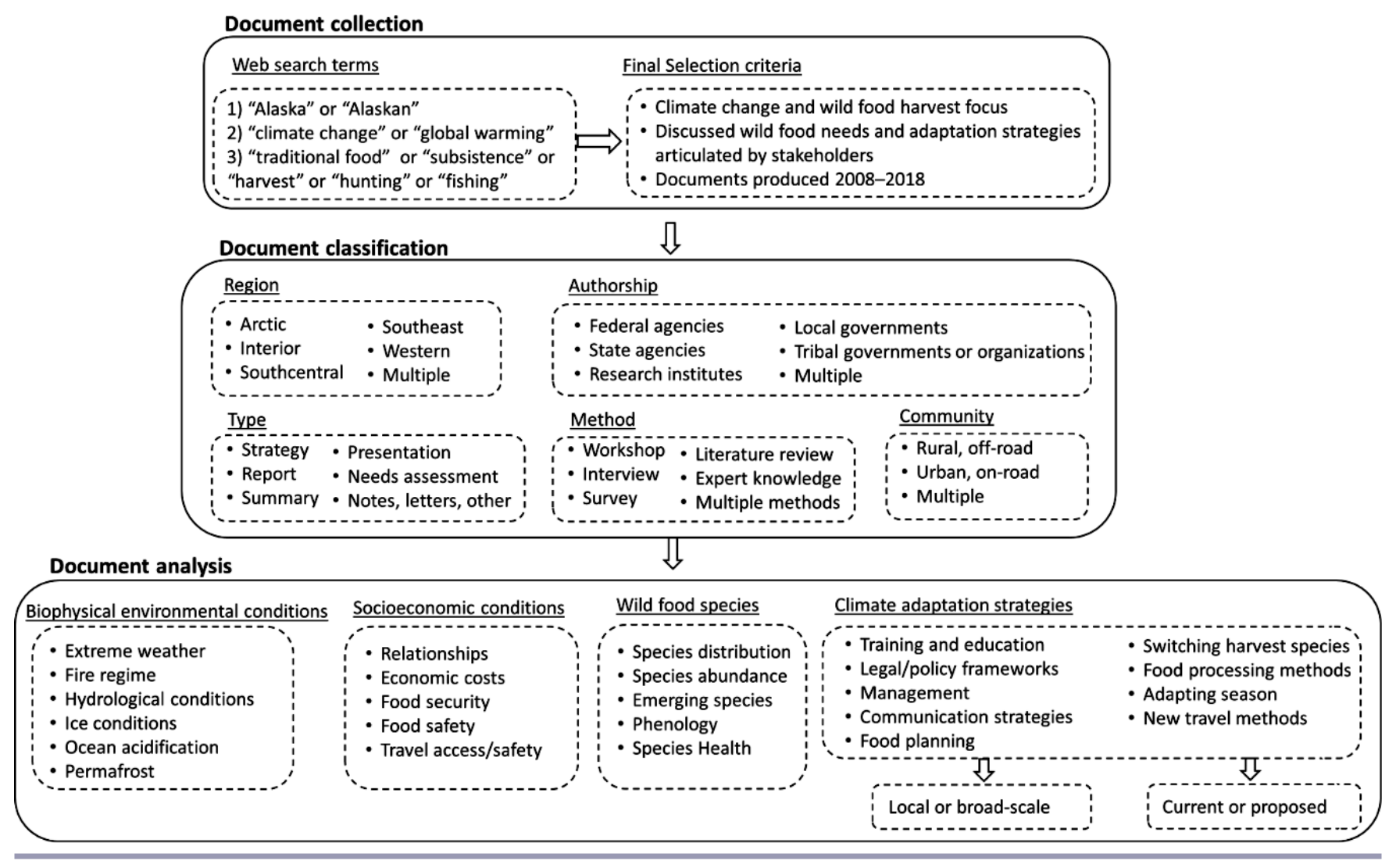

social networks to share resource conditions. At the same time, several rapid climate-related changes have made these adaptive responses less reliable, e.g., shifting distribution of sea ice to harvest marine mammals (Huntington et al. 2016) and others more difficult, e.g., time constraints from employment (Pearce et al. 2015). Wild food gathering requires flexibility to harvest resources that are accessible, and the ability to make modifications to take advantage of resource availability given localized conditions (Ford et al. 2009, Brinkman et al. 2016). Thus, adaptation strategies are often opportunistic and depend on the ability of individuals or local groups to make changes to harvest strategies such as substitutions when resources are unavailable (Nuttall et al. 2005, Ford et al. 2006). However, with changing environmental conditions, adaptations in harvest timing and location also require broader institutional support in policy and regulatory reform at the state or federal level (Kofinas et al. 2010, McNeeley 2012, Huntington et al. 2017).

Given the importance of wild foods in rural communities in Alaska, there is demand to better understand how Alaskan harvesters are adapting to changing climate and what knowledge gaps can be filled by credible information. First, it is critical to understand overarching information needs as they relate to food harvest so that they can be prioritized and addressed by decision makers. Second, although there is an extensive literature that documents the multiple climate adaptation strategies for subsistence and food security in the Arctic (Ford and Pearce 2010, Pearce et al. 2012, Pearce et al. 2015, Berner et al. 2016) there remains a limited understanding of local adaptive capacity as it relates to information needs. Our objectives with this paper are to (1) describe what observations are being made within the grey literature about wild foods in the context of climate change; (2) express what information needs are identified in relation to climate change impacts on wild food harvest; and (3) characterize what climate change-related harvest adaptation strategies are proposed and already being implemented, and how these efforts may be enhanced by resource management and policy actions.

\section{METHODS}

\section{Document collection}

To gather and retain documents, we used a combination of web and document word searches (Fig. 1, Appendix 1). Web searches were designed to collect documents that focused on three themes: (1) Alaska; (2) global climate warming; and (3) wild food harvest. We chose a set of search terms that were indicative of the three preliminary themes (Fig. 1, Box 1). To ensure that we were collecting all possible documents, we tried a series of permutations with combinations of search terms. We evaluated the combination of terms by the volume of content produced and if content was related to the three preliminary themes. Additionally, we bounded our search by assessing documents that were produced from 2008 to 2018. Following our web search, documents were imported into NVIVO and reviewed using word searches that included the original search terms. Each document was then individually reviewed to ensure that content addressed 
wild foods needs and adaptation strategies (Fig. 1, Box 1). Here, wild food harvest refers to hunting, fishing, and gathering activities that supports the livelihoods of Alaskan residents including customary and traditional uses of Alaska's fish and wildlife resources, e.g., subsistence hunting and fishing. Documents were typically created by organizations such as local, state, regional governments, and tribal councils (Appendix 1). Several of these documents were produced by more than one organization or in collaboration with multiple groups. Given the diversity of contributors, we broadly characterized all groups as "stakeholders," or non-academic entities that are likely to be impacted by climate effects on wild foods. Stakeholders included wild food harvesters, tribal community members, tribal organizations, state and federal agencies and non-profits. Documents created by research institutions were only included if they assessed the needs of a stakeholder group in order to inform local management and decision making. Peer reviewed journal articles were not included in the document review. Prior to document analysis, we confirmed our document sample through conversations with local experts in different sectors.

\section{Document classification}

To classify documents, we recorded the name(s) and type of organization, e.g., state agency, that created or wrote the document, where we found the document, e.g., website URL, type of document, methodology, as well as the year it was published (Appendix 1). Finally, to provide information regarding the geographic scope of the documents, we recorded the region and whether the community was on or off the road system. If a document focused broadly on wild foods across the state or focused on > two regions, we assigned it a "Multiple" regions classification. We summarized these classifications by providing the percentage of total documents that were coded in each group.

\section{Document analysis}

We used qualitative content analysis methods to assess (1) stakeholder observations related to climate effects on wild food harvest; (2) information needs directly associated with climate effects on wild food harvest; and (3) what adaptations were being proposed and implemented to meet stakeholder needs (Fig. 1). Content analysis is a methodology that groups sections of text related to similar themes, to identify thematic patterns across documents (Bernard and Ryan 2010). Our design included both deductive (concepts related to our analytical framework) and inductive (emergent themes related to research questions) elements. This "hybrid" approach to coding is appropriate for exploratory studies because it allows for document concepts to shape on-going analysis (Bryman 2016). We began with a coding list based on prior research of Alaskan climate change needs (Knapp and Trainor 2013, 2015) and then expanded on this list to include wild food harvest themes and concepts. Once the preliminary rounds of coding were conducted, we used the word search feature to confirm that we had labeled all themes within each document. Documents were coded twice by a single coder to make sure all stated themes were captured. We did not track how stakeholders' needs and adaptation strategies changed overtime. Additionally, if documents were produced by more than one stakeholder group, we did not separate the various observations made by groups because it was difficult to distinguish the various viewpoints. Hierarchical coding reports were used to summarize how often a theme was coded and how many documents included a specific theme.
To summarize the information, we coded documents into three major climate-related themes: wild food species, biophysical environmental conditions that affect wild food harvest, and socioeconomic conditions that result from unpredictable wild food harvest. Impacts to wild food species included needs statements or observations related to changes in species-level populations, geographic distribution, or health. Biophysical environmental conditions included statements related to environmental or climatic changes to species habitat or the biophysical environmental conditions associated with wild food harvest. Changing socioeconomic conditions include statements related to economic, cultural, and health costs associated with unpredictable wild food harvest. Coded statements were then placed into subthemes within each category (Fig. 1, Appendix 2). We presented the percentage of total documents that included statements related to stakeholder observations of the various subthemes. These statements were associated with direct observations or experiences individuals or communities encountered while harvesting wild foods. We also quantified the total number of coded statements mentioning a research or information need related to the same major sub-themes. The information needs statements were assertions for more information, data, or strategies related to wild food harvest in the context of climate change.

Finally, we coded statements related to adaptation strategies associated with climate-related changes to wild foods. Adaptation strategies were any actions that stakeholders employed to offset the negative consequences associated with climate change impacts on wild food resources (Appendix 2). We differentiated between current strategies being implemented at the time of writing from those that were proposed and still in need of implementation. Additionally, we recorded if adaptation strategies were being implemented at the local scale, i.e., adaptations from within communities, or at broader scale outside the jurisdiction of stakeholder groups. Local-scale adaptations include strategies adopted by individual harvesters, tribal councils, or local governments. Broad-scale adaptations were strategies proposed at the regional or state level, or were strategies proposed within a community, but could not be implemented without the support of regional, state, or national institutions.

\section{RESULTS}

\section{Document information}

We collected and analyzed 87 documents through web searches related to climate change in the context of wild food harvest in Alaska. Organizations that created documents included state agencies $(20 \%)$ and federal agencies $(22 \%)$, tribal governments or organizations $(25 \%)$, research institutions ( $8 \%$ ), multiple agencies (21\%), and local governments (4\%; see Appendix 1, Column 5). Documents in the review were created using expert knowledge $(32 \%)$, workshops $(22 \%)$, surveys/interviews $(16 \%)$, and literature reviews $(10 \%)$. Several documents $(20 \%)$ utilized more than one method to assess climate change needs. The majority of documents covered multiple regions (42\%) in Alaska (Fig. 2), followed by Arctic (27\%) and Western (24\%) Alaskan communities. Far fewer documents focused directly on Interior $(3 \%)$, Southeast $(2 \%)$, and Southcentral $(2 \%)$ communities. Of these communities, $47 \%$ of documents were classified as off-road communities (i.e., communities off the Alaskan road system), < $5 \%$ classified as urban, on-road communities (i.e., city centers 
connected to the highway system), $<5 \%$ rural, on-road communities (i.e., connected to the highway system, but in remote parts of the state). The rest of our documents (46\%) represented both on and off-road communities across Alaska (Fig. 2).

Fig. 2. Map of five major Alaskan regions, proportion of documents reporting needs for each region, and communitytype.

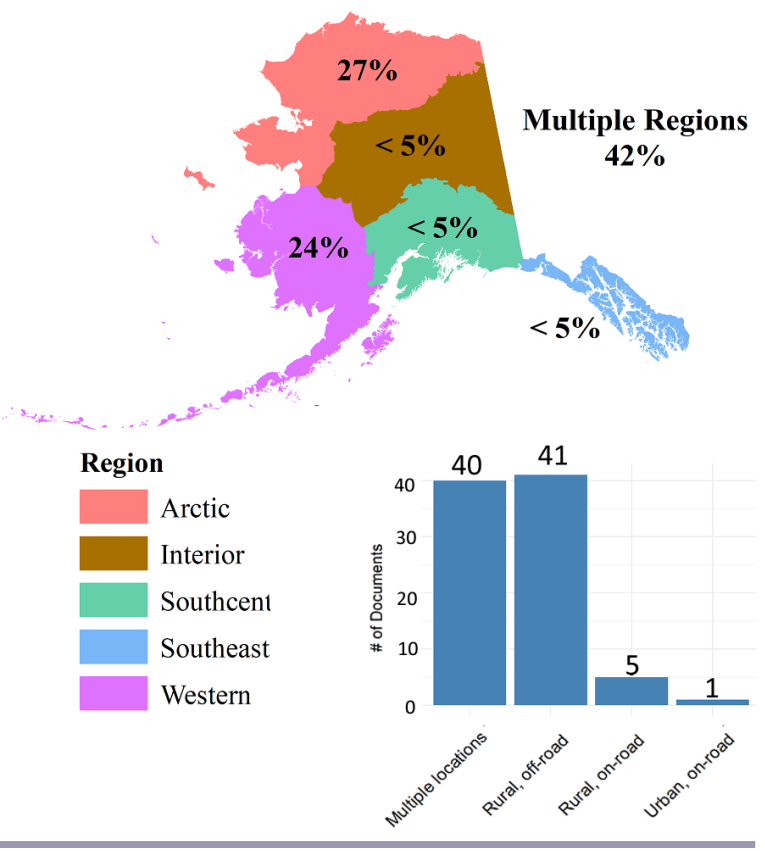

\section{Observed changes to wild food resources}

Nearly half $(48 \%)$ of the documents described observations that wild food species are changing as a result of climate change. Almost half of all documents (47\%) stated that the geographic distributions of traditionally harvested wildlife, fish and plant species have shifted on the landscape. Stakeholders also noted that wild food species have changed in abundance (36\%). Over a third of documents $(35 \%)$ observed emerging or new species that may impact or interact with harvest species. Several documents $(28 \%)$ also identified that the timing (phenology) of when species can be found across their range has shifted.

Stakeholder documents $(40 \%)$ described that the biophysical environmental conditions that support habitat and access to wild foods have also changed. Over a third of the documents $(35 \%)$ referenced observed changes in river ice and sea ice conditions including changes to ice coverage, thickness, and timing of formation. Some documents $(29 \%)$ stated that hydrological conditions are changing and could have important implications on Alaskan riparian and aquatic harvested species. Stakeholders also stated that changes to the wildfire regime, such as increased fire severity, extent, and frequency, have affected habitat conditions for harvested species. Other important biophysical transformations included permafrost degradation $(11 \%)$ and ocean acidification $(10 \%)$.

The majority of stakeholder documents $(60 \%)$ describe some socioeconomic impacts related to climate change and wild food species. Half the documents (50\%) stated changes to interpersonal connections or relationships, which included statements on community connections, and self-worth or self-identity. As one document stated,

\section{Food is the cornerstone of our culture and self-and shared identity. Harvesting of traditional foods is how cultural values, skills, and spirituality are learned - this is how all learn to be within their environments and to be part of the ecosystem. (Appendix 1, \#16)}

Over a third of documents $(41 \%)$ identified safety and travel concerns related to traditional harvest users accessing resources. Stakeholder documents also stated the impacts on community food security (44\%) and safety (37\%). Other important socioeconomic impacts included economic costs associated with loss of harvest resources $(32 \%)$ and increased development in areas used for traditional harvest $(13 \%)$.

\section{Stakeholder information needs}

Species distribution $(n=121)$ was the most frequently discussed information need related to climate effects on wild food species (Fig. 3). Species abundance $(\mathrm{n}=78)$, novel or emerging species $(n=73)$, phenological changes $(n=64)$, and species health $(n=$ 47) were also regularly mentioned climate change information needs (Fig. 3). Ice conditions $(n=114)$ were referenced most as an information need related to changing biophysical environmental conditions impacting wild food harvest. Other biophysical information needs included extreme weather $(n=65)$, hydrological conditions $(n=62)$, fire regimes $(n=32)$, permafrost degradation $(n=30)$, and ocean acidification $(n=18$; Fig. 4$)$. Finally, relationships $(n=141)$ were the most commonly stated information need related to impacts on the socioeconomic conditions related to changing wild food harvest. Travel access and safety $(n=136)$, food security $(n=100)$, food safety $(n=94)$, and economic costs $(n=56)$ were also frequently discussed information needs (Fig. 5).

Fig. 3. Stakeholder information needs related to wild food species (2008-2018).

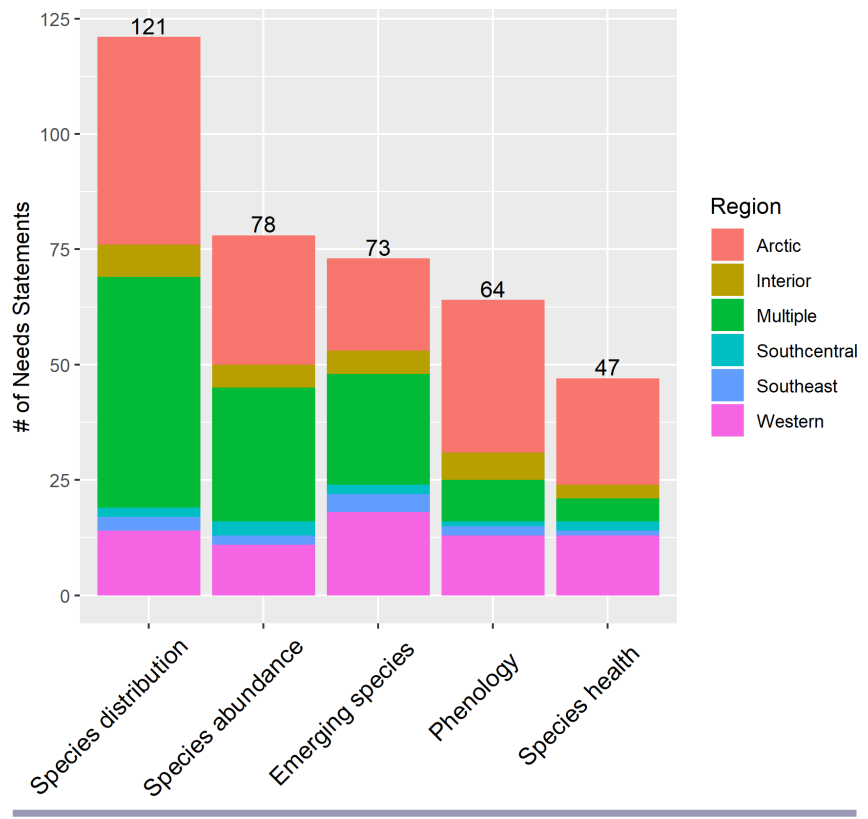


Fig. 4. Stakeholder information needs related to biophysical environmental conditions that affect wild food harvest (20082018).

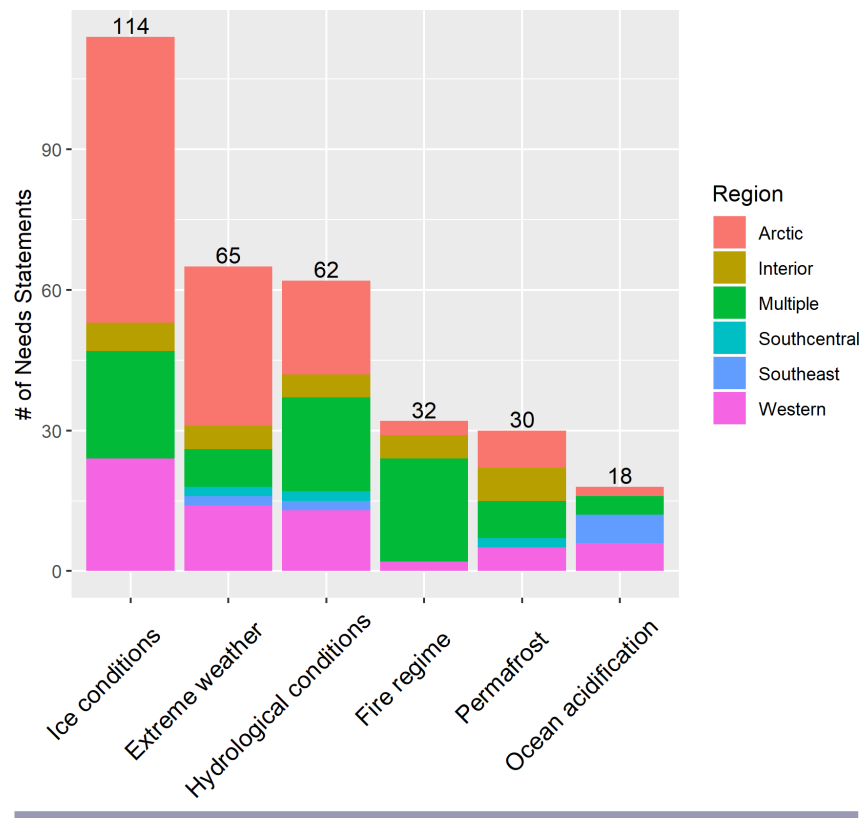

Fig. 5. Stakeholder information needs related to socioeconomic conditions that result from unpredictable harvest (2008-2018).

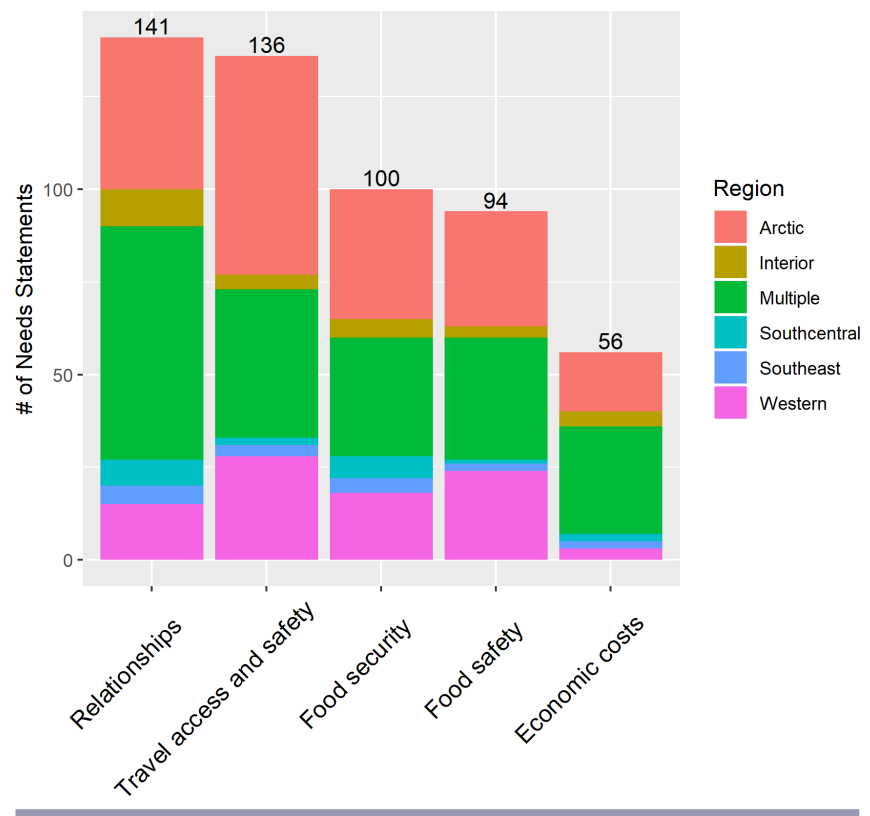

\section{Adaptation strategies}

Forty-two percent of documents described various adaptation strategies that help communities cope with changes to traditional harvest practices. Most of the proposed adaptation strategies stated the need for adaptable management $(30 \%)$ and legal and policy frameworks $(12 \%)$. Management refers to actionable, applied decision-making strategies for natural resource managers, whereas adaptable legal and policy frameworks refer to the processes and procedures that guide management of natural resources (Appendix 2). Switching harvest species (9\%), training opportunities $(10 \%)$, new communication strategies $(7 \%)$, as well as improved techniques to process and store foods $(8 \%)$ were other common strategies that still needed to be implemented by stakeholders. The vast majority of those strategies were proposed $(n=136$ statements $)$ or have not yet been implemented compared to strategies that have already been adopted $(\mathrm{n}=55$ statements) by local residents or organizations (Fig. 6). Most of the current adaptation strategies that have been adopted are localized and employed by groups of individuals within communities $(n=55$ statements), versus at broader-scales ( $\mathrm{n}=32$ statements). For example, switching harvest species, adapting harvest season, and community food planning are a few strategies that have been incorporated into local practice. However, most of the adaptation strategies ( $n=150$ statements) that still need to be implemented are being proposed at a broader-level scale (e.g., state government), than at the local level ( $\mathrm{n}=91$ statements). One document stated,

The challenge for environmental and resource management agencies will be to manage for healthy, productive ecosystems in a future made less certain due to a changing climate. This will necessitate possible changes to their institutional, legal and policy frameworks to respond quickly enough to sustain the natural resources they manage for the public trust. (Appendix 1, \#8)

Fig. 6. Number of harvester statements that addressed both current and proposed climate-related adaptation strategies to wild food harvest. Adaptation strategies were recorded at the local scale (i.e., adaptations from within communities or user groups, orange bars), and at the broad scale (i.e., outside the jurisdiction of user groups, green bars).

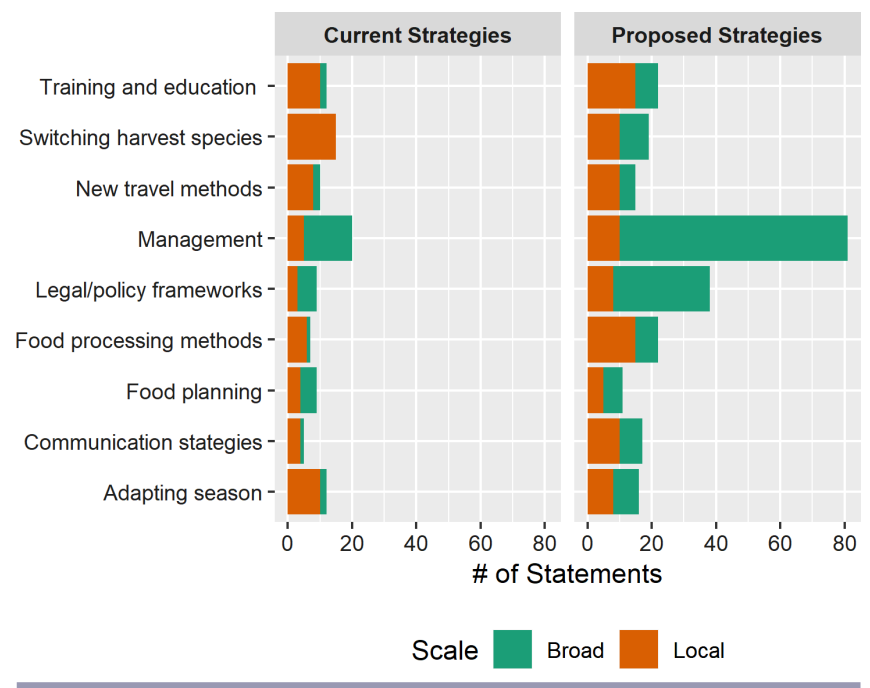




\section{DISCUSSION}

Observations of biophysical system reverberate to social system An increased understanding of what local people are seeing and how it relates to their needs could improve the dialog regarding the relevance of climate change research (Knapp and Trainor 2013). Almost half of the documents described alterations to biophysical environmental conditions that can impact harvesters directly by changing access, affecting food storage, and shifting modes of transportation. Changing sea ice and hydrological conditions were the most common observations reported in our search. Sea ice is an essential component for indigenous hunters that harvest marine mammals and is changing rapidly. These changes affect hunters by transforming access and altering the safety and effectiveness of ice as a substrate for hunting (Huntington et al. 2016, 2017). Thinner ice can create dangerous conditions leading to injuries and equipment damage (Mahoney et al.2009). During the summer, people navigate large waterbodies by boat to harvest fish species or to access remote hunting areas. Our findings are consistent with other recent studies that document community concerns related to variable breakup and freeze-up conditions (McNeeley and Shulski 2011, Jones et al. 2015), which have led to reduced access to harvest areas (Brinkman et al. 2016). Documents also spoke broadly about changes in extreme weather events affecting both safety and access to wild food resources. For example, more frequent storms have led to fewer safe boating days, which can reduce hunting opportunities for marine species. Several documents described how changes in permafrost degradation could alter the hydrology of lakes and rivers that have traditionally been used to access wild foods. Additionally, harvesters observed how permafrost degradation affects the utility of traditional ice cellars, which has implications for food safety and security.

Documents suggested that species are shifting their distributions in space, e.g., home ranges, and time, e.g., seasonal migration, which has implications for the availability of these resources for local hunters. Shifting spatial distributions of wild food resources might require hunters to travel further or acquire new modes of transportation, all of which have added economic costs (Brinkman et al. 2014). Increases in temperature over the last century have clearly been linked to shifts in the geographic range of fauna, with the largest changes occurring across tundra ecoregions (Lawler et al. 2009). Given the magnitude of projected temperature changes in Alaska, it can be expected that species will continue to disperse into new suitable areas (USGCRP 2018). Changing patterns of species distribution and abundance are very likely linked to observations of shifting biophysical habitat conditions (Marcot et al. 2015). Examples include declines in lacustrine environments affecting migratory birds or shifting sea ice influencing spatial use patterns of marine mammals. Additionally, shifting environmental conditions during controlled hunting seasons may impact the harvest of wildlife resources (Hasbrouck et al. 2020). Documents also described novel interactions between new species and current species. The arrival of invasive species presents a whole new set of conservation and management concerns, whereas the appearance of game species could present new harvest opportunities.

In some cases, new subsistence resources are becoming available. In other cases, nuisance animals or predators that compete with people have hampered the success of subsistence activities. (Appendix 1, \#31)

The majority of documents expressed that climate change-driven effects to wild food resources were impacting socioeconomic conditions within their communities. Fifty percent of reviewed documents described changes to interpersonal connections and relationships within their communities. This result acknowledges the importance of the wild food system from a social perspective, recognizing the importance of all aspects of harvesting, preparing, consuming, and sharing wild foods. Sharing food is an important cultural practice, and although it minimizes the risk of food insecurity, sharing also connects community members socially (Collings et al. 1998). One document stated,

Food is the cornerstone of our culture and self-and shared
identity. Harvesting of traditional foods is how cultural
values, skills and spirituality are learned-this is how all
learn to be within their environments and to be part of
the ecosystem. The relationship between Inuit andall else
that makes up the Arctic environment aids in the
maintenance of cultural and environmental integrity.
(Appendix 1, \#16)

Documents also described that climate change has negatively affected the accessibility of wild food resources. Previous work has documented the disproportionately large effects of perceived climate-driven changes on travel to subsistence resources (Porter et al. 2014, Brinkman et al. 2016, Cold et al. 2020). The ability to access wild foods is essential for Arctic food security (Lambden et al. 2007) and changing environmental conditions can not only reduce the ability to procure wild foods, but can also impact the safety and well-being of local harvesters (Brubaker et al. 2011, Clark et al. 2016).

\section{Harvest adaptation strategies}

Our review found that most current adaptations are decisions being made locally within communities to manage the risks of current climate change on wild food harvest in Alaska. Most of these strategies include finding new areas to hunt, substituting harvest species, or using new modes of travel. Research has shown that Arctic wild food harvesters have demonstrated significant adaptability in the face of changing resource conditions (Cruikshank 2001, Ford et al. 2006). Adjusting to accommodate changes to wild foods is likely one of the primary adaptations because harvesters can improvise strategies related to travel, such as deciding the mode of access, as opposed to confronting largescale changes to biophysical habitat conditions. These current strategies suggest that there are adaptions being employed to manage changing conditions and are indicative of localized adaptive capacity to future climate change. Additionally, documents described several current broad-scale adaptation strategies that were being implemented and planned by organizations at the regional or state level. For example, regional food planning activities, such as harvest and storage workshops, were being organized across multiple communities (Appendix 1, \#16, 65, 69). Several documents described local observers collecting information about environmental change that was then linked to regional observation networks (Appendix 1, \#35, 36, 37, 39). 
Our review also identified adaptation strategies that still need to be implemented including several proposed legal, policy, and management actions. For example, documents called for extending hunting seasons, increasing bag limits, and changing resource access regulations because of unusual weather patterns and the inability to meet harvest needs (Appendix \#1, \#2, 48, 65, $69,73)$. Our results are consistent with other studies that have proposed changes to hunting seasons to increase local access to natural resources and allow for more adaptive regional wildlife management (McNeeley 2012). Many of the strategies that were not yet implemented were categorized as "broad-scale," and needed to be coordinated and adopted at levels outside of local communities.

\section{Barriers to adaptation}

An increasing number of studies have identified commonly reported barriers to climate change adaptations (Biesbroek et al. 2013, Eisenack et al. 2014, Piggott-McKellar et al. 2019), including financial and institutional obstacles (Ekstrom and Moser 2014). Our review identified several local adaptation strategies, such as finding new areas to hunt or adopting new techniques to harvest wild foods that hinged on finding financial resources for implementation to happen on the ground. Barriers related to new economic costs were identified by $>30 \%$ documents. Increasing costs associated with accessing areas to hunt, such as requiring more expensive equipment and larger amounts of fuel, may prohibit traditional wild food gathering practices. One document asserted,

\section{The increasing cost of participating in subsistence activities and dramatic changes in the social context of Arctic indigenous communities are causing a seeming decline in local fishing and hunting knowledge and level of participation in subsistence practices. (Appendix 1, Document \#2)}

Several reviewed documents also stated that the management of wild foods was hindered by outdated policies based on historical factors that do not account for climate change. This barrier was usually mentioned in relation to resource management and local access to subsistence resources. One document stated,

Adaptable legal and policy frameworks, many laws, regulations and policies on the federal, state, and local levels were developed for a static environment where climate change was not recognized. The challenge for government leaders and businesses will be to adapt to a future made less certain due to a more rapidly changing climate. This will necessitate an evaluation of existing laws, regulations and policies and possible changes to institutional, legal and policy frameworks in an adaptive manner. (Appendix 1, Document \#8)

The failure to recognize localized problems is a common mismatch between scales of management institutions (Schultz et al. 2019). Documents recommended that local harvesters should be involved in the decision-making process. Such efforts can develop capacity for community-driven projects and create supportive relationships with a wider network of actors. One document stated,

It helps to have people working for land management agencies who have lived in the area for a long time, who know and understand the local way of life. Local people can also provide information about the land and resources that helps researchers and agencies do their work better. Can decision-making move to the community level in some way?" (Appendix 1, \#69).

Finally, policy makers and managers must often make difficult decisions regarding natural resource populations based on past conditions with limited and often incomplete baseline data (Nichols et al. 2011). Several documents describe the need for better data on both biophysical habitat and socioeconomic conditions to make more informed decisions. Increased harvest reporting, in particular, was described as a tool needed to assess the variability and extent of adaptive uses of fish and wildlife resources.

\section{Opportunities for future work and management directions}

Our review highlights topics, scales of organization, and regions that could benefit from additional information to better understand wild food harvester needs as they relate to changing resource conditions. Opportunities for adaptation exist for resource managers and other local decision makers when management strategies are adaptive and incorporate an understanding of climate variability in conjunction with local observations and resource needs. It will be important for researchers and managers to consider resource availability and accessibility, which accounts for not only the abundance of wild foods, but also for seasonal variations, spatial distributions, and obstacles to access (Brown et al. 2015, Brinkman et al. 2016). The ability to predict altered spatial distributions varies dramatically by species (Sekercioglu et al. 2008), and presents challenges to managers developing and implementing comprehensive strategies that mitigate the effects of climate changes on wild foods. However, developing future distribution models for key wild foods (e.g., Baltensperger and Joly 2019) could help agencies start planning efforts to access new areas to allow hunting. Additionally, it is possible that climate change could produce dramatic changes in the abundance of new subsistence species that would prompt a reconsideration of available management actions. For example, new fishing opportunities are opening in the Arctic (Carothers et al. 2019); however, failure to effectively manage new species could result in conflict with commercial fisheries and lost food security opportunities. It is also conceivable that climate change, including increased precipitation and temperature, will produce widespread habitat changes that may provide new opportunities for harvest, but also new needs for adaptive habitat management.

Documents call for a more responsive system that is flexible and accounts for high resource variability. Harvesters have proposed or already adopted adaptation strategies to meet changing conditions, but their actions will need a regulatory system that is quick to respond to in-season changes to resources (McNeeley 2012). Researchers should consider whether localized, improvised adaptations are effectively meeting the needs of local harvesters, or if they are being hindered by adaptive mismatch across management entities, e.g., state/federal agencies. Future work could identify where mismatch is occurring for important wild foods and whether newly designed policy and management tools could further enhance local adaptations while maintaining the legal and policy obligations of the institution. Boundary work to 
support cross-scale arrangements such as improving communication across governance levels and local harvesters would greatly enhance future adaptive capacity (Cash et al. 2006). Additionally, scenario planning could also provide opportunities for communication between resource managers and local communities that will aid decision making under wild food resource uncertainty (Knapp et al. 2017).

Documents strongly voiced the need for new, adaptive decisionmaking strategies to manage fisheries, wildlife, and other wild foods resources. This result is consistent with the co-management literature that states that both local and indigenous knowledge can complement knowledge generation (Berkes 2009) and the management of wild food resources (Armitage 2005, Armitage et al. 2011). Knowledge partnerships in a management setting can bring together different entities, build trust, resolve conflict, and allow for more efficient joint problem solving (Kofinas 2009). Previous work has recommended that climate change science can be more relevant if it includes integration of different forms of knowledge, user driven science, and regionally grounded stakeholder suggestions (Dilling and Lemos 2011, Ford et al. 2013, Kalafatis et al. 2015, Stone 2020). Significant partnership with local communities can encourage user-driven science including products and deliverables that could be used by harvesters grappling with food insecurity, unsafe travel conditions, and maintaining cultural connections to the land (Chapin et al. 2016).

\section{Limitations of research}

In this review, we did not conduct a longitudinal analysis to assess how stakeholder needs and adaptation strategies changed over time. It is conceivable that contemporary needs have shifted in importance over the past decade or that harvester observations have fluctuated as they experience new conditions over time. Additionally, it is feasible that individuals, communities, and institutions have generated new adaptation strategies in the meantime that were not captured in this review. We also bounded our document search over a 10-year period (2008-2018) and only analyzed documents that met our search criteria. This left out meeting notes, e.g., subsistence resource committees, that may have been relevant but did not meet our criteria. Furthermore, stakeholders could have produced documents that were indirectly related to climate change or wild foods, but did not use our search terms and were subsequently missed in our web search. Here, we focused on the needs and adaptation strategies that were described most frequently across documents. We assumed that needs and adaptations that were more frequently expressed corresponded with a greater need, while others that were described less frequently, were not as important. It is also possible that the geographic distribution of the grey literature influenced the number of stated research needs. It was difficult to evaluate the variation in needs among regions because of the high proportion of documents created for multiple regions; however, our analysis does highlight places, e.g., Southcentral, where additional assessment might be needed. Finally, although we recognize that several partnerships have been implemented over the past decade targeting Alaskan climate change needs, it was not our intent to evaluate these, but to focus on what was being said by harvesters in the grey literature. Despite these challenges and assumptions, this review of the grey literature is a useful and available indicator of Alaskan harvester needs.

\section{CONCLUSIONS}

Amplified climate change in Alaska has altered the relationship between harvesters and local wild food resources. In wild food harvest systems, climate change directly impacts biophysical habitat conditions that are linked to species dynamics and the socioeconomic well-being of communities. Our review contributes to climate change needs and adaptation literature by examining a body of work, i.e., grey literature, to identify locally grounded observations of changing resource conditions and remaining information needs to inform direct actions. The findings from this study support recent research (McNeeley et al. 2012, Herman-Mercer et al. 2019) that wild food adaptation actions emerged locally, but broader legal, policy, and management frameworks were still needed to adapt to rapid climate change. The results demonstrate that coordination is required at regional and national levels to ensure wild food harvesters can adapt planning and management activities. This assessment has provided insight into the ways in which organizations may adapt to maintain food security, health, and cultural connections as an integral component to their lifestyle changes.

Responses to this article can be read online at: https://www.ecologyandsociety.org/issues/responses. php/12509

\section{Acknowledgments:}

This publication is the result in part of research sponsored by the National Oceanic and Atmospheric Administration grants NA11OAR4310141 and NA16OAR4310162, the Alaska Center for Climate Assessment and Policy, the United States Department of Agriculture (USDA), Alaska Climate Adapters: Developing Community-Based Capacity to Meet Critical Adaptation Needs (2017-68002-26726), the USDA National Institute of Food and Agriculture, Hatch project 1018914, and the state of Alaska.

\section{Data Availability:}

Document were derived from the following resources available in the public domain: document URLs can be found listed in Appendix 1: column 4.

\section{LITERATURE CITED}

Armitage, D. 2005. Adaptive capacity and community-based natural resource management. Environmental Management 35:703-715. https://doi.org/10.1007/s00267-004-0076-Z

Armitage, D., F. Berkes, A. Dale, E. Kocho-Schellenberg, and E. Patton. 2011. Co-management and the co-production of knowledge: learning to adapt in Canada's Arctic. Global Environmental Change 21(3):995-1004. https://doi.org/10.1016/ j.gloenvcha.2011.04.006

Baltensperger, A. P., and K. Joly. 2019. Using seasonal landscape models to predict space use and migratory patterns of an Arctic 
ungulate. Movement Ecology 7:18. https://doi.org/10.1186/ s40462-019-0162-8

Berkes, F. 2009. Evolution of co-management: role of knowledge generation, bridging organizations, and social learning. Journal of Environmental Management 90:1692-1702. https://doi. org/10.1016/j.jenvman.2008.12.001

Bernard, H. R., and G. W. Ryan. 2010. Analyzing qualitative data: systematic approaches. SAGE, Thousand Oaks, California, USA.

Berner, J., M. Brubaker, B. Revitch, E. Kreummel, M. Tcheripanoff, and J. Bell. 2016. Adaptation in Arctic circumpolar communities: food and water security in a changing climate. International Journal of Circumpolar Health 75(1):33820. https://doi.org/10.3402/ijch.v75.33820

Biesbroek, G. R., J. E. M. Klostermann, C. J. A. M. Termeer, and P. Kabat. 2013. On the nature of barriers to climate change adaptation. Regional Environmental Change 13(5):1119-1129. https://doi.org/10.1007/s10113-013-0421-y

Brinkman, T., G. Kofinas, W. Hansen, F. S. Chapin, and S. Rupp. 2013. A new framework to manage hunting. Wildlife Professional 7:38-43.

Brinkman, T., K. T. B. Maracle, J. Kelly, M. Vandyke, A. Firmin, and A. Springsteen. 2014. Impact of fuel costs on high-latitude subsistence activities. Ecology and Society 19(4):18. http://dx.doi. org/10.5751/ES-06861-190418

Brinkman, T. J., W. D. Hansen, F. S. Chapin III, G. Kofinas, S. BurnSilver, and T. S. Rupp. 2016. Arctic communities perceive climate impacts on access as a critical challenge to availability of subsistence resources. Climatic Change 139:413-427. https://doi. org/10.1007/s10584-016-1819-6

Brown, C. L., K. A. Seaton, T. J. Brinkman, E. S. Euskirchen, and K. Kielland. 2015. Applications of resilience theory in management of a moose-hunter system in Alaska. Ecology and Society 20(1):16. http://dx.doi.org/10.5751/ES-07202-200116

Brown, D. R., T. J. Brinkman, D. L. Verbyla, C. L. Brown, H. S. Cold, and T. N. Hollingsworth. 2018. Changing river ice seasonality and impacts on interior Alaskan communities. Weather, Climate, and Society 10(4):625-640. https://doi. org/10.1175/WCAS-D-17-0101.1

Brubaker, M., J. Berner, R. Chavan, and J. Warren. 2011. Climate change and health effects in northwest Alaska. Global Health Action 4:8445. http://doi.org/10.3402/gha.v4i0.8445

Bryman, A. 2016. Social research methods. Oxford University Press, Oxford, UK.

Carothers, C., T. L. Sformo, S. Cotton, J. C. George, and P. A. Westley. 2019. Pacific salmon in the rapidly changing Arctic: exploring local knowledge and emerging fisheries in Utqiagivik and Nuiqsut, Alaska. Arctic 72(3):273-288. https://doi. org/10.14430/arctic68876

Cash, D. W., W. Adger, F. Berkes, P. Garden, L. Lebel, P. Olsson, L. Pritchard, and O. Young. 2006. Scale and cross-scale dynamics: governance and information in a multilevel world. Ecology and Society 11(2):8. https://doi.org/10.5751/ES-01759-110208
Chapin III, F. S., C. N. Knapp, T. J. Brinkman, R. Bronen, and P. Cochran. 2016. Community-empowered adaptation for selfreliance. Current Opinion in Environmental Sustainability 19:67-75. https://doi.org/10.1016/j.cosust.2015.12.008

Chen, H., J. Zou, J. Cui, M. Nie, and C. Fang. 2018. Wetland drying increases the temperature sensitivity of soil respiration. Soil Biology and Biochemistry 120:24-27. https://doi. org/10.1016/j.soilbio.2018.01.035

Clark, D. G., J. D. Ford, L. Berrang-Ford, T. Pearce, S. Kowal, and W. A. Gough. 2016. The role of environmental factors in search and rescue incidents in Nunavut, Canada. Public Health 137:44-49. https://doi.org/10.1016/j.puhe.2016.06.003

Cold, H. S., T. J. Brinkman, C. L. Brown, T. N. Hollingsworth, D. R. N. Brown, and K. M. Heeringa. 2020. Assessing vulnerability of subsistence travel to effects of environmental change in Interior Alaska. Ecology and Society 25(1):20. https:// doi.org/10.5751/ES-11426-250120

Collings, P., G. Wenzel, and R. G. Condon. 1998. Modern food sharing networks and community integration in the central Canadian Arctic. Arctic 51(4):301-314. https://doi.org/10.14430/ $\underline{\operatorname{arctic} 1073}$

Cruikshank, J. 2001. Glaciers and climate change: perspectives from oral tradition. Arctic 54(4):377-393. https://doi. org/10.14430/arctic795

Dilling, L., and M. C. Lemos. 2011. Creating usable science: opportunities and constraints for climate knowledge use and their implications for science policy. Global Environmental Change 21 (2):680-689. https://doi.org/10.1016/j.gloenvcha.2010.11.006

Eisenack, K., S. C. Moser, E. Hoffmann, R. J. Klein, C. Oberlack, A. Pechan, M. Rotter, and C. J. Termeer. 2014. Explaining and overcoming barriers to climate change adaptation. Nature Climate Change 4:867-872. https://doi.org/10.1038/nclimate2350

Ekstrom, J. A., and S. C. Moser. 2014. Identifying and overcoming barriers in urban climate adaptation: case study findings from the San Francisco Bay Area, California, USA. Urban Climate 9:54-74. https://doi.org/10.1016/j.uclim.2014.06.002

Euskirchen, E. S., A. D. McGuire, F. S. Chapin, and T. S. Rupp. 2010. The changing effects of Alaska's boreal forests on the climate system. Canadian Journal of Forest Research 40:1336-1346. https://doi.org/10.1139/X09-209

Ford, J. D. 2009. Vulnerability of Inuit food systems to food insecurity as a consequence of climate change: a case study from Igloolik, Nunavut. Regional Environmental Change 9:83-100. https://doi.org/10.1007/s10113-008-0060-X

Ford, J. D., M. Knight, and T. Pearce. 2013. Assessing the 'usability' of climate change research for decision-making: a case study of the Canadian International Polar Year. Global Environmental Change 23(5):1317-1326. https://doi.org/10.1016/ j.gloenvcha.2013.06.001

Ford, J. D., and T. Pearce. 2010. What we know, do not know, and need to know about climate change vulnerability in the western Canadian Arctic: a systematic literature review. Environmental Research Letters 5:011001. https://doi.org/10.1088/1748-9326/5/1/014008 
Ford, J. D., and T. Pearce. 2012. Climate change vulnerability and adaptation research focusing on the Inuit subsistence sector in Canada: directions for future research. Canadian Geographer/Le Géographe Canadien 56:275-287. https://doi.org/10.1111/ j.1541-0064.2012.00418.x

Ford, J. D., B. Smit, and J. Wandel. 2006. Vulnerability to climate change in the Arctic: a case study from Arctic Bay, Canada. Global Environmental Change 16(2):145-160. https://doi. org/10.1016/j.gloenvcha.2005.11.007

Hasbrouck, T. R., T. J. Brinkman, G. Stout, E. Trochim, and K. Kielland. 2020. Quantifying effects of environmental factors on moose harvest in Interior Alaska. Wildlife Biology 2. https://doi. org/10.2981/wlb.00631

Herman-Mercer, N. M., M. Laituri, M. Massey, E. Matkin, R. Toohey, K. Elder, P. F. Schuster, and E. Mutter. 2019. Vulnerability of subsistence systems due to social and environmental change: a case study in the Yukon-Kuskokwim Delta, Alaska. Arctic 72(3):258-272. https://doi.org/10.14430/ $\underline{\operatorname{arctic} 68867}$

Hinzman, L. D., N. D. Bettez, W. R. Bolton, F. S. Chapin, M. B. Dyurgerov, C. L. Fastie, B. Griffith, R. D. Hollister, A. Hope, H. P. Huntington, et al. 2005. Evidence and implications of recent climate change in northern Alaska and other arctic regions. Climatic Change 72:251-298. https://doi.org/10.1007/s10584-005-5352-2

Huntington, H. P., L. T. Quakenbush, and M. Nelson. 2016. Effects of changing sea ice on marine mammals and subsistence hunters in northern Alaska from traditional knowledge interviews. Biology Letters 12:20160198. https://doi.org/10.1098/ $\underline{\text { rsbl.2016.0198 }}$

Huntington, H. P., L. T. Quakenbush, and M. Nelson. 2017. Evaluating the effects of climate change on indigenous marine mammal hunting in northern and western Alaska using traditional knowledge. Frontiers in Marine Science 4:319. https:// doi.org/10.3389/fmars.2017.00319

Jones, C. E., K. Kielland, L. D. Hinzman, and W. S. Schneider. 2015. Integrating local knowledge and science: economic consequences of driftwood harvest in a changing climate. Ecology and Society 20(1):25. http://dx.doi.org/10.5751/ES-07235-200125

Jorgenson, M. T., V. Romanovsky, J. Harden, Y. Shur, J. O'Donnell, E. A. Schuur, M. Kanevskiy, and S. Marchenko. 2010. Resilience and vulnerability of permafrost to climate change. Canadian Journal of Forest Research 40:1219-1236. https://doi. org/10.1139/X10-060

Kalafatis, S. E., M. C. Lemos, Y. J. Lo, and K. A. Frank. 2015. Increasing information usability for climate adaptation: the role of knowledge networks and communities of practice. Global Environmental Change 32:30-39. https://doi.org/10.1016/j. gloenvcha.2015.02.007

Kasischke, E. S., D. L. Verbyla, T. S. Rupp, A. D. McGuire, K. A. Murphy, R. Jandt, J. L. Barnes, E. E. Hoy, P. A. Duffy, M. Calef, and M. R. Turetsky. 2010. Alaska's changing fire regimeimplications for the vulnerability of its boreal forests. Canadian Journal of Forest Research 40:1313-1324. https://doi. org/10.1139/X10-098
Kettle, N., J. Martin, and M. Sloan. 2017. Nome tribal climate adaptation plan. Nome Eskimo Community and the Alaska Center for Climate Assessment and Policy, Fairbanks, Alaska, USA.

Knapp, C. N., N. L. Fresco, and L. Krutikov. 2017. Managing Alaska's National Parks in an era of uncertainty: an evaluation of scenario planning workshops. Regional Environmental Change 17(5):1541-1552. https://doi.org/10.1007/s10113-017-1126-4

Knapp, C. N., and S. F. Trainor. 2013. Adapting science to a warming world. Global Environmental Change 23(5):1296-1306. https://doi.org/10.1016/j.gloenvcha.2013.07.007

Knapp, C. N., and S. F. Trainor. 2015. Alaskan stakeholderdefined research needs in the context of climate change. Polar Geography 38(1):42-69. https://doi.org/10.1080/1088937X.2014.999844

Kofinas, G. P. 2009. Adaptive co-management in social-ecological governance. Pages 77-101 in F. S. Chapin III, G. P. Kofinas, and C. Folke, editors. Principles of ecosystem stewardship. Springer, New York, New York, USA. https://doi.org/10.1007/978-0-387-73033-2_4

Kofinas, G. P., F. S. Chapin, S. BurnSilver, J. I. Schmidt, N. L. Fresco, K. Kielland, S. Martin, A. Springsteen, and T. S. Rupp. 2010. Resilience of Athabascan subsistence systems to interior Alaska's changing climate. Canadian Journal of Forest Research 40:1347-1359. https://doi.org/10.1139/X10-108

Lambden, J., O. Receveur, and H. V. Kuhnlein. 2007. Traditional food attributes must be included in studies of food security in the Canadian Arctic. International Journal of Circumpolar Health 66:308-319. https://doi.org/10.3402/ijch.v66i4.18272

Lawler, J. J., S. L. Shafer, D. White, P. Kareiva, E. P. Maurer, A. R. Blaustein, and P. J. Bartlein. 2009. Projected climate-induced faunal change in the Western Hemisphere. Ecology 90:588-597. https://doi.org/10.1890/08-0823.1

Liljedahl, A. K., J. Boike, R. P. Daanen, A. N. Fedorov, G. V. Frost, G. Grosse, L. D. Hinzman, Y. Iijma, J. C. Jorgenson, N. Matveyeva, et al. 2016. Pan-Arctic ice-wedge degradation in warming permafrost and its influence on tundra hydrology. Nature Geoscience 9(4):312-318. https://doi.org/10.1038/ngeo2674

Loring, P. A., and S. C. Gerlach. 2015. Searching for progress on food security in the North American North: a research synthesis and meta-analysis of the peer-reviewed literature. Arctic 68 (3):380-392. http://dx.doi.org/10.14430/arctic4509

Lynn, K., J. Daigle, J. Hoffman, F. Lake, N. Michelle, D. Ranco, C. Viles, G. Voggesser, and P. Williams. 2014. The impacts of climate change on tribal traditional foods. Pages 37-48 in $\mathbf{J}$. Koppel Maldonado, B. Colombi, and R. Pandya, editors. Climate change and indigenous peoples in the United States. Springer International, Cham, Switzerland. https://doi.org/10.1007/978-3-319-05266-3_4

Mahoney, A., S. Gearheard, T. Oshima, and T. Qillaq. 2009. Sea ice thickness measurements from a community-based observing network. Bulletin of the American Meteorological Society 90:370-378. https://doi.org/10.1175/2008BAMS2696.1 
Marcot, B. G., M. T. Jorgenson, J. P. Lawler, C. M. Handel, and A. R. DeGange. 2015. Projected changes in wildlife habitats in Arctic natural areas of northwest Alaska. Climatic Change 130:145-154. https://doi.org/10.1007/s10584-015-1354-X

McNeeley, S. M. 2012. Examining barriers and opportunities for sustainable adaptation to climate change in Interior Alaska. Climatic Change 111:835-857. https://doi.org/10.1007/s10584-011-0158$\underline{\mathrm{x}}$

McNeeley, S. M., and M. D. Shulski. 2011. Anatomy of a closing window: vulnerability to changing seasonality in Interior Alaska. Global Environmental Change 21(2):464-473. https://doi. org/10.1016/j.gloenvcha.2011.02.003

Meeker, D., and N. Kettle. 2017. A synthesis of climate adaptation planning needs in Alaska Native Communities. Alaska Center for Climate Assessment and Policy, Fairbanks, Alaska, USA. [online] URL: https://uaf-accap.org/wp-content/uploads/2019/08/SynthesisCAP-Alaska-Native-Communities 2017.pdf

Miller, C. A., and C. Wyborn. 2020. Co-production in global sustainability: histories and theories. Environmental Science and Policy 113:88-95. https://doi.org/10.1016/j.envsci.2018.01.016

Nichols, J. D., M. D. Koneff, P. J. Heglund, M. G. Knutson, M. E. Seamans, J. E. Lyons, J. M. Morton, M. T. Jones, G. S. Boomer, and B. K. Williams. 2011. Climate change, uncertainty, and natural resource management. Journal of Wildlife Management 75(1):6-18. https://doi.org/10.1002/jwmg.33

Nuttall, M., F. Berkes, B. C. Forbes, G. Kofinas, T. Vlassova, and G. Wenzel. 2005. Hunting, herding, fishing and gathering: indigenous peoples and renewable resource use in the Arctic. Pages 649-690 in Arctic climate impact assessment. Cambridge University Press, Cambridge, UK.

Pearce, T., J. Ford, A. Caron, and B. Kudlak. 2012. Climate change adaptation planning in remote, resource-dependent communities: an Arctic example. Regional Environmental Change 12:825-837. https://doi.org/10.1007/s10113-012-0297-2

Pearce, T., J. Ford, A. Willox, and B. Smit. 2015. Inuit traditional ecological knowledge (TEK), subsistence hunting and adaptation to climate change in the Canadian Arctic. Arctic 68(2):233-245. http://dx.doi.org/10.14430/arctic4475

Pearson, R. G., S. J. Phillips, M. M. Loranty, P. S. Beck, T. Damoulas, S. J. Knight, and S. J. Goetz. 2013. Shifts in Arctic vegetation and associated feedbacks under climate change. Nature Climate Change 3:673-677. https://doi.org/10.1038/ nclimate 1858

Piggott-McKellar, A. E., K. E. McNamara, P. D. Nunn, and J. E. Watson. 2019. What are the barriers to successful communitybased climate change adaptation? A review of grey literature. Local Environment 24(4):374-390. https://doi.org/10.1080/1354$\underline{9839.2019 .1580688}$

Porter, J. R., L. Xie, A. J. Challinor, K. Cochrane, S. M. Howden, M. M. Iqbal, D. B. Lobell, and M. I. Travasso. 2014. Food security and food production systems. Pages 485-534 in C. B. Field, V. R. Barros, D. J. Dokken, K. J. Mach, M. D. Mastrandrea, T. E. Bilir, M. Chatterjee, K. L. Ebi, Y. O. Estrada, R. C. Genova, B. Girma, E. S. Kissel, A. N. Levy, S. MacCracken, P. R. Mastrandrea, and
L. L. White, editors. Climate change 2014: impacts, adaptation and vulnerability. Part A: global and sectoral aspects. Contribution of Working Group II to the Fifth Assessment Report of the Intergovernmental Panel on Climate Change. Cambridge University Press, Cambridge, UK. https://doi. org/10.1017/cbo9781107415379.012

Schultz, C. A., T. J. Timberlake, Z. Wurtzebach, K. B. McIntyre, C. Moseley, and H. R. Huber-Stearns. 2019. Policy tools to address scale mismatches: insights from U.S. forest governance. Ecology and Society 24(1):21. https://doi.org/10.5751/ES-10703-240121

Sekercioglu, C. H., S. H. Schneider, J. P. Fay, and S. R. Loarie. 2008. Climate change, elevational range shifts, and bird extinctions. Conservation Biology 22(1):140-150. https://doi. org/10.1111/j.1523-1739.2007.00852.x

Stafford Smith, M., L. Horrocks, A. Harvey, and C. Hamilton. 2011. Rethinking adaptation for a $4^{\circ} \mathrm{C}$ world. Philosophical Transactions of the Royal Society A: Mathematical, Physical and Engineering Sciences 369:196-216. https://doi.org/10.1098/ $\underline{\text { rsta.2010.0277 }}$

Stone, R. 2020. Indigenous Alaskans demand a voice in research on warming. Science 369(6509):1284-1285. https://doi.org/10.1126/ science.369.6509.1284

Tribbia, J., and S. C. Moser. 2008. More than information: what coastal managers need to plan for climate change. Environmental Science and Policy 11(4):315-328. https://doi.org/10.1016/j. envsci.2008.01.003

U.S. Global Change Research Program (USGCRP). 2018. Impacts, risks, and adaptation in the United States: Fourth national climate assessment, Volume II. D. R. Reidmiller, C. W. Avery, D. R. Easterling, K. E. Kunkel, K. L. M. Lewis, T. K. Maycock, and B. C. Stewart, editors. U.S. Global Change Research Program, Washington, D.C., USA. https://doi. org/10.7930/NCA4.2018

Van Daele, L. J., J. R. Morgart, M. T. Hinkes, S. D. Kovach, J. W. Denton, and R. H. Kaycon. 2001. Grizzlies, Eskimos, and biologists: cross-cultural bear management in southwest Alaska. Ursus 1:141-152.

Wotkyns, S., and C. González-Maddux. 2014. Climate change adaptation planning training, assistance, and resources for Tribes report: developed for U.S. Federal agencies working on Tribal climate change programs and initiatives. Northern Arizona University and Institute for Tribal Environmental Professionals, Flagstaff, Arizona, USA. 
Appendix 1. Document information including title (Column 2), date published (Column 3), where we found the document (website; Column 4), the name and type (e.g., state agency; Column 5) of organization that created the document, type of document (e.g., report, Column 6), methodology (Column 7), geographic region (Column 8), and if the region was on or off the road system (Column 8).

\begin{tabular}{|c|c|c|c|c|c|c|c|c|}
\hline$\#$ & Title & Date & URL & $\begin{array}{c}\text { Organization } \\
\text { Name and Type }\end{array}$ & $\begin{array}{c}\text { Type of } \\
\text { Document }\end{array}$ & Method & Region & Community \\
\hline 1 & $\begin{array}{l}\text { A Summary of the Alaskan } \\
\text { Marine Arctic Conservation } \\
\text { Action Plan for the Chukchi } \\
\text { and Beaufort seas }\end{array}$ & 2010 & $\begin{array}{l}\text { https://www.adaptationcle } \\
\text { aringhouse.org/resources/a } \\
\text {-summary-of-the-alaskan- } \\
\text { marine-arctic- } \\
\text { conservation-action- } \\
\text { plan.html }\end{array}$ & $\begin{array}{l}\text { The Nature } \\
\text { Conservancy } \\
\text { (Nonprofit) }\end{array}$ & Strategy & Workshop & Arctic & Rural, Off-road \\
\hline 2 & $\begin{array}{l}\text { A Synthesis of Climate } \\
\text { Adaptation Planning Needs in } \\
\text { Alaska Native Communities }\end{array}$ & 2017 & $\begin{array}{l}\frac{\text { https://accap.uaf.edu/sites/ }}{\text { default/files/resources/Me }} \\
\text { eker\%20and\%20Kettle\%2} \\
\text { 02017_Synthesis\%20CAP } \\
\text { \%20Alaska\%20Native\%2 } \\
\text { 0Communities.pdf }\end{array}$ & $\begin{array}{l}\text { Alaska Center for } \\
\text { Climate Assessment } \\
\text { and Policy } \\
\text { (Research Institute) }\end{array}$ & Report & $\begin{array}{l}\text { Literature } \\
\text { Review }\end{array}$ & Multiple & Rural, Off-road \\
\hline 3 & $\begin{array}{l}\text { A Ten-Year Prioritization of } \\
\text { Infrastructure Needs in the } \\
\text { U.S. Arctic }\end{array}$ & 2016 & $\begin{array}{l}\text { https://www.cmts.gov/do } \\
\text { wnloads/NSAR_1.1.2_10- } \\
\text { Year_MTS_Investment_F } \\
\text { ramework_Final_5_4_16. } \\
\text { pdf }\end{array}$ & $\begin{array}{l}\text { U.S. Department of } \\
\text { Transportation } \\
\text { (Working Group) }\end{array}$ & Strategy & $\begin{array}{l}\text { Expert } \\
\text { Knowledge }\end{array}$ & Arctic & Rural, Off-road \\
\hline 4 & $\begin{array}{l}\text { Adapting to Climate Change: } \\
\text { A Call for Federal Leadership }\end{array}$ & 2010 & $\begin{array}{l}\underline{\text { https://www.c2es.org/site/ }} \\
\text { assets/uploads/2010/04/ad } \\
\text { apting-to-climate-change- } \\
\text { call-for-federal- } \\
\text { leadership.pdf }\end{array}$ & $\begin{array}{l}\text { Pew Center on } \\
\text { Global Climate } \\
\text { Change (Nonprofit) }\end{array}$ & Strategy & $\begin{array}{l}\text { Expert } \\
\text { Knowledge }\end{array}$ & Multiple & Multiple \\
\hline 5 & $\begin{array}{l}\text { Alaska's Climate Change } \\
\text { Strategy }\end{array}$ & 2010 & $\begin{array}{l}\text { https://www.cakex.org/cas } \\
\text { e- } \\
\text { studies/alaska\%E2\%80\%9 } \\
\text { 9s-climate-change- } \\
\text { strategy }\end{array}$ & $\begin{array}{l}\text { Alaska Adaptation } \\
\text { Advisory Group } \\
\text { (Working Group) }\end{array}$ & Strategy & $\begin{array}{l}\text { Expert } \\
\text { Knowledge }\end{array}$ & Multiple & Multiple \\
\hline 6 & $\begin{array}{l}\text { Alaska Climate Change } \\
\text { Strategy: Health and Culture } \\
\text { Technical Working Group }\end{array}$ & 2008 & $\begin{array}{l}\text { https://dec.alaska.gov/clim } \\
\text { ate-change/ }\end{array}$ & $\begin{array}{l}\text { Alaska Department } \\
\text { of Environmental } \\
\text { Conservation (State } \\
\text { Agency) }\end{array}$ & Summary & $\begin{array}{l}\text { Expert } \\
\text { Knowledge }\end{array}$ & Multiple & Multiple \\
\hline 7 & $\begin{array}{l}\text { Alaska Climate Impact } \\
\text { Assessment: A } \\
\text { Commissioners Summary of } \\
\text { Findings }\end{array}$ & 2008 & $\begin{array}{l}\text { http://bonnernetwork.pbw } \\
\text { orks.com/f/comissioner+re } \\
\text { port.pdf }\end{array}$ & $\begin{array}{l}\text { Alaska Climate } \\
\text { Impact Assessment } \\
\text { Commission (State } \\
\text { Agency) }\end{array}$ & Presentation & $\begin{array}{l}\text { Expert } \\
\text { Knowledge }\end{array}$ & Multiple & Multiple \\
\hline
\end{tabular}


Alaska DOT \& PF Adaptation

to Climate Change

Alaska Energy Research Needs

11 Alaska Region Climate

Change Response Strategy 2010-2014

12 Alaska State Climate Change Policy

13 Alaska Wildland Fire Coordinating Group Fire Research Needs 201

$14 \quad$ Alaska Wildland Fire Coordinating Group Needs

Alaska's Climate Change Strategy: Public Infrastructure and Climate Change
2010 http://www.adfg.alaska.go $\mathrm{v} /$ static/lands/ecosystems/ pdfs/climatechangestrateg y.pdf

No http://climatechange trans Date portation.org/pdf/gregovic hadot.pdf

2010 ftp://ftp.aidea.org/2010Ala skaEnergyPlan $/ 2010 \% 20$ Alaska\%20Energy\%20Pla $\mathrm{n} /$ Research\%20Needs\%20

Assessment/Research\%20 Needs\%20Assessment.pdf

2010 http://www.nps.gov/akso/ docs/AKCCRS.pdf

2017 https://dec.alaska.gov/clim ate-change/

011 http://fire.ak.blm.gov/cont ent/admin/awfcg_committ ees/Fire\%20Research\%20

Development\%20and\%20 Application/c.\%20AWFC G_Fire\%20Research\%20 Needs_2011_Final.pdf

2017 https://fire.ak.blm.gov/con tent/admin/awfcg_commit tees/Fire\%20Research\%2

Development\%20and\%20

Application/c.\%20AWFC

G_research_needs_list_20

17.pdf

$2012 \quad$ Not available
Alaska Department of Fish and Game (State Agency)

Alaska Department

of Transportation

(State Agency)

The Alaska Center for Energy and Power

(Research Institute)

National Park

Service (Federal Agency)

Alaska Department of Environmental Conservation (State Agency)

Bureau of Land

Management

(Federal Agency)

Bureau of Land

Management

(Federal Agency)

Alaska Department of Transportation

(State Agency)
Strategy

Literature

Multiple

Multiple

Review

Presentation

Expert

Multiple

Multiple

Knowledge

Expert

Multiple

Multiple

Report

Knowledge

Strategy

Expert

Knowledge

Multiple

Multiple

Summary

Expert

Multiple

Multiple

Knowledge

Expert

Multiple

Multiple

Needs

Knowledge

Assessment

Knowledg

Expert

Multiple

Multiple Knowledge

Multiple

Expert
Knowledge

Multiple 
17 Aleutian and Bering Sea

Islands Landscape

Conservation Cooperative

Strategic Science Plan

Workshop Report

18 Aleutian and Bering Sea

Islands Landscape

Conservation Cooperative

Strategic Science Plan

19 American Indian and Alaska

Native Climate Change

Project

20 Arctic Landscape

Conservation Cooperative

Future Needs Assessment

21 Arctic Landscape

Conservation Cooperative

Strategic Science Plan

22 Arctic Ocean Synthesis:

Analysis of Climate Change

Impacts in the Chukchi and

Beaufort Seas with Strategies

For Future Research

2015 https://iccalaska.org/wp-

icc/wp-

content/uploads/2016/03/F

ood-Security-Summary-

and-Recommendations-

Report.pdf

2013 https://lccnetwork.org/site

s/default/files/Resources/

ABSI\%20LCC\%20Strate

ic\%20Science\%20Plan\%2

0Workshop\%20Report.pd

uit Circumpolar

Council-Alaska

Summary

Multiple

Arctic

Multiple

(n)

Methods

Workshop

Western

Rural, Off-road

Sea Islands

Landscape

Conservation

Cooperative

(Federal Agency)

2015 https://lccnetwork.org/site

s/default/files/Resources/

ABSI\%20LCC\%20Strate

ic\%20Science\%20Plan.pd

$\mathrm{f}$

Sea Islands

Strategy

Landscape

Conservation

Cooperative

(Federal Agency)

2011 https://www.fs.fed.us/pnw /pubs/pnw gtr944.pdf

US Department of

Agriculture and

Survey

Multiple

Multiple

Oregon State

University (Multiple

Organizations)

2013 http://arcticlcc.org/project

s/management/future-

Arctic Landscape

Conservation

Needs

Assessment

Interview

Arctic

Cooperative

(Federal Agency)

2013 http://arcticlcc.org/assets/a

bout/scienceplan/ALCC_S

trategic_Science

Arctic Landscape

Strategy

Survey

Arctic

(Federal Agency)

2008 http://www.arcodiv.org/ne ws/NPRB_report2_final.p $\underline{\mathrm{df}}$

Institute Of Marin

Sciences (Federal

Report

Expert

Arctic and

Knowledge Western

Alaska
Rural, Off-road

Rural, Off-road

ral, Off-road 
Health Impacts of Climate

Change in Alaska

Building Food Security in Alaska

Changing Conditions in the Arctic: Strategic Action Plan

Chugach Regional Resource Commission Climate Change Workshop Outcomes

Chukchi Sea and Norton

Sound Observation Network: Harvest and Use of Wild

Resources in 9 Communities

in Arctic Alaska

27 Climate Change and Health Effects in the Bristol Bay Region of Alaska Impacts Point Hope, Alaska
2018 http://www.epi.alaska.gov /bulletins/docs/rr2018_01. pdf

\section{Department of \\ Health and Social}

Services (State

Agency)

2014 https://www.crcworks.org/ akfood.pdf

Department Health and Social

Services and Alaska

Food Policy Council

(State Agency)

2011 http://www.whitehouse.go v/sites/default/files/micros ites/ceq/sap_8_arctic_full content outline 06-02-

2016

\section{1 clean pdf}

https://tribalclimateguide. uoregon .edu/literature/20 6-chugach-regionalresources-commission-

climate-change-workshopoutcomes

2017 https://www.arlis.org/docs /vol1/M/993004497.pdf

\section{Multiple \\ Organizations}

Chugach Regional

Resources

Commission (State Agency)

Alaska Department of Fish and Game (State Agency)

2014 https://anthc.org/wpcontent/uploads/2016/01/ CCH AR 042014 Clima e-Change-Bristol-BayRegion.pdf

https://www.cidrap.umn.e c/php/26952/Climate\%20 Change\%20HIA\%20Repo rt_Point\%20Hope 0.pdf

Bristol Bay Native Bay Area Health

Corporation, Alaska Native Tribal Health Consortium (Tribal

Government or

Organization)

Alaska Native
Tribal Health
Consortium (Tribal
Government or

\section{Summary}

Literature Review

Multiple

Multiple

Summary

Interview

Multiple

Multiple

Expert

Knowledg

Arctic

Summary

Workshop

Southcentral

Urban, On-road Association, Bristol

Summary

Literature

Western

Rural, Off-road
Summary

Survey

Western

Rural, Off-road 
Climate Change and

Indigenous Peoples- A

Synthesis of Current Impacts

and Experiences

30 Climate Change and Private

Forest Landowners in Alaska:

A Needs Assessment

Climate Change and

Subsistence: What it means to

Alaskans and how we can

adapt

Climate change: anticipated effects on ecosystem services and potential actions by the Alaska Region, U.S. Forest Service

34 Climate Change Impact Assessment for Surface

Transportation in the Pacific Northwest and Alaska

35 Climate Change in Atqasuk, Alaska Strategies for Community Health

Community Health
2016 https://www.fs.fed.us/pnw /pubs/pnw_gtr944.pd

2011 http://s3-us-west-

2.amazonaws.com/wp2.ca

hnrs.wsu.edu/wp-

content/uploads/sites/32/2 019/04/P2259.pdf

No https://seagrant.uaf.edu/bo

okstore/download.php?loc $=$ fla $\% 2 \mathrm{FM}-139 \% 2 \mathrm{FM}-$ 139PDF.pdf\&amp;pub $=\mathrm{M}$

139PDF\&amp;title=Clima te+Change+and+Subsiste ce\%3A+What+It+Means+ to\&amp;bypass=TRUE

2012 No Longer Available

2010 http://www.fs.usda.gov/Int US Forest Service ernet/FSE_DOCUMENTS (Federal Agency) /fsbdev2_038171.pdf

2012 http://www.wsdot.wa.gov/ research/reports/fullreport s/772.1.pdf

2015 https://anthc.org/wp-

content/uploads/2016/01/ CCH AR 072014 Clima e-Change-in-Atqasuk.pdf

2011 http://www.anthc.org/chs/ ces/climate/upload/Climat e-Change-in-Kivalina-

Alaska-Strategies-for-

Community-Health-2.pdf
US Forest Service (Federal Agency)

US Department of Agriculture (Federal Agency)

US Forest Service and Washington State (Multiple

Organizations)

Alaska SeaGrant Marine Advisory Program, National

Oceanic and

tmospheric

Administratiple

Organizations)

Washington State

Department of

Transportation

(State Agency)

Alaska Native

Tribal Health

Consortium (Tribal

Government or

Organization)

Alaska Native

Tribal Health

Consortium (Tribal

Government or

Organization)
Report

\section{Literature}

Multiple

Multiple Review

Needs

Assessment

Expert

Multiple

Multiple

Knowledge

Notes, letter

Expert

Knowledge

Western

Multiple

or other

Presentation

Expert

Multiple

Multiple

Knowledge

Summary

Literature

Multiple

Multiple Review

Needs

Multiple

Methods

Multiple

Multiple

Assessment

Report

Multiple

Arctic

Rural, Off-road

Methods

(n)

Strategy

Interview

Arctic

Rural, Off-road 
Climate Change in Levelock,

Alaska Strategies for

2013

https://anthc.org/wp-

Alaska Native

Report

Multiple

Consortium (Tribal

Methods

Western

Rural, Off-road

e-Change-in-Levelock.pdf Government or

Organization)

Climate Change in Nondalton,

2015

Alaska Strategies for

Climate Change in Nuiqsut,

Alaska Strategies for

2014 https://anthc.org/wp-

Climate Change in Pilot Point,

Alaska Strategies for

Community Health

2015 https://anthc.org/wp-

$41 \quad$ Climate change in Point

Hope, Alaska: Strategies for

Community Health

2010 https://www.cakex.org/site

42 Climate Change in Selawik,

Alaska Strategies for

Community Health

Climate change in the Bering Strait Region

2016 https://anthc.org/wp-

2015 https://lccnetwork.org/reso

Government or

https://anthc.org/wp-

Alaska Native

content/uploads/2016/01/

CCH_AR_112013_Climat

e-Change-in-

Tribal Health

Consortium (Tribal

Nondalton.pdf

Government or

Organization)

Alaska Native

content/uploads/2016/01/

CCH AR 072014 Climat

e-Change-in-Nuiqsut.pdf

Consortium (Triba

Government or

Organization)

content/uploads/2016/01/

Tribal Health

CCH AR 092013 Climat

ortium (Tribal

e-Change-in

Government or

PilotPoint.pdf

Organization)

s/default/files/documents/

CCH_AR_082010_Climat

e-Change-in-Point-

Alaska Native

Tribal Health

Consortium (Tribal

Hope.pdf

(n)

Organization)

Alaska Native

content/uploads/2016/01/

CCH_AR_052012_Climat

e-Change-in-Selawik.pdf

Consortium (Triba

Government or

Organization)

Alaska Native

urce/climate-change-

Tribal Health

Consortium (Triba

Report Multiple Western Rural, Off-road

Methods

Multiple

Methods

Arctic

Rural, Off-road

Multiple
Methods

Multiple

Methods

Western

Rural, Off-road

Report

Multiple

Methods

Western

Rural, Off-road

Report

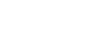

(1)

Report

Multiple

Multiple

Western

Rural, Off-road

bering-strait-region
Organization) 
Wainwright.pd

Methods

https://irma nps. gov/DataS

\section{Climate Change Water} Infrastructure Forum

Community Observations on Climate Change: Nushagak River Trip Report

Community Observations on

Climate Change: Arctic

Village, Fort Yukon and

Venetie, Alaska

Cultural Resources Climate

Change Strategy

50 Current coastal change projects and priority information needs in Western Alaska

Elim Hazard Impact Statement /DownloadFile/49778

Service (Federal

Agency)

2008 Not available

201

http $/ /$ anthc.org/wp content/uploads/2016/01/ CCH AR 092014 Climat

e-Change-and-UpperNushagak-River.pdf

2016 https://anthc.org/wpcontent/uploads/2016/01/ Upper-Yukon-RiverClimate-AssessmentFinal.pdf

2017 https://www.nps.gov/subje cts/climatechange/cultural resourcesstrategy.htm

2015 https://accap.uaf.edu/proje ct/current-coastal-changeresearchmanagementprojects-and-priority-

information-needs-western

\section{Environmenta Protection Agency} (Federal Agency)

Alaska Native Tribal Health Consortium (Tribal

Government or Organization)

Alaska Native

Tribal Health

Consortium (Tribal

Government or

Organization)

National Park

Service (Federal

Agency)

Alaska Center for

Climate Assessment and Policy and

Western Landscape

Multiple

Organizations

2012 http://www.commerce.stat e.ak.us/dca/planning/acci
City of Elim (Local Agency)
Workshop Interior and Rural, On-road Arctic

Workshop Multiple Multiple

Multiple

Methods

Western

Rural, Off-road

Summary

Summary Survey

Interior and

Arctic

Multiple

Multiple

Methods

Literature

Western

Rural, Off-road

Assessment Review

ultiple Methods
Western

Rural, Off-road 
$\mathrm{mp} /$ Elim.html

Emerging Issue Summary:

North Slope Science Initiative

53

Experts Workshops to

Comparatively Evaluate

Coastal Current and Ice

Movements in the

Northeastern Chukchi Sea

54 Exploring Stakeholder Needs

for Coastal Research in a

Rapidly Changing Arctic

Exploring the Subsistence Fisheries of Point Lay and

Wainwright, Alaska

Food Security and Wild

Resource Harvests in Alaska

Hazard Impact Assessment: Kipnuk, AK
Initiative Oversigh

Group (Multiple

Organizations)

2014 https://www.uaf.edu/cfos/r International Arctic esearch/projects/expertsworkshops-to-comp/

Research Cente

(Research Institute)

2018 https://climatechange.uma Maine, Arctic

ing-stakeholder-needscoastal-research-rapidlychanging-arcticl

Landscape

Conservation

Cooperative, Arctic

Borderlands

Ecological

Knowledge Society

(Multiple

Organizations)

2016 https://www.arlis.org/docs /vol1/M/965293136.pdf

Alaska Department of Fish and Game

(State Agency)

2018 http://www.adfg.alaska.go v/static/home/subsistence/ pdfs/food security whitep aper.pdf

2011 https://www.commerce.ala ska.gov/web/dcra/Plannin gLandManagement/ACCI MP/HazardImpactAssess ments/KipnukHIA.aspx
Alaska Department of Fish and Game

(State Agency)

Alaska Department of Commerce,

Community, and

Economic

Development,

Kipnuk Traditiona

Council (Multiple

Organizations)
Report

Summary

Multiple

Methods

Arctic

Rural, Off-road

Report

Workshop Arctic

Rural, Off-road

Summary

Interview

Arctic

Rural, Off-road

Multiple

Methods

Arctic

Rural, Off-road

Summary

Expert

Knowledge

Multiple

Multiple

Summary

Multiple

Methods 
Climate Change: A Report

Outlining the Research Needs

on the Human Health Effects

of Climate Change

Health Problems Heat up

Immediate Action

Workgroup:

Recommendations to the

Governor's Subcabinet on

Climate Change

61 Impacts of Climate Change on Tribes in the United States

Implications of Climate Change and Research Needs for Coastal Processes in Cold Regions

63 Kotzebue Meeting Notes: Improving Local participation in research in Northwest Alaska
2010 http://www.niehs.nih.gov/ health/assets/docs_a_e/cli matereport2010.pdf

National Institute of

Health, National

Needs

Expert

Multiple

Multiple

Oceanic and

Atmospheric

Administration,

Center for Disease

Control and

Prevention (Federal

Agencies)

2007 Not available

Trust for American's Report

Health (Non-profit)

2009 https://dec.alaska.gov/med ia/4558/immediate-actionworkgroup-final-report-

Alaska Governor

Subcabinet on

Climate Change 12-mar-09.pdf

(State Agency)

2009 Not available

National Tribal Air Association (Tribal

Government or

Organization)

2009

Not available

Multiple

Organizations

http://www.arcus.org/files/
page/documents/893/lccko
tzebuenotes.pdf
tzebuenotes.pdf

\section{Western Alaska}

Landscape

Conservation

Cooperative, Arctic

Research

Consortium o the

U.S., Northwest

Arctic Borough,

Noorvik Native

Community, Native

Village of Kotzebue

(Multiple

Agencies)

2011 http://www.aebfish.org/nl/ hiaNL102811.pdf
Summary

Multiple

Western

Rural, Off-road

$\begin{array}{lll}\text { Expert } & \text { Multiple } & \text { Multiple } \\ \text { Knowledge } & & \end{array}$

Expert

Arctic

Multiple

Expert Multiple Multiple

Knowledge

Expert

Knowledge

Multiple

Multiple

Notes, letters Workshop Arctic

Rural, Off-road
Methods
Aleutians East

Agency) 
Optimizing Military Training

Land Use into the Future, $\mathrm{NH}$

Joint Engineering Society

Conference

Prioritized fire research topics for Alaska

Priority Information Needs:

Federal Subsistence Fisheries

Promoting Resilience Adaptation: A Synthesis from Four Regional Workshops in Alaskan Arctic

Research Needs Work Group: Recommendations on

Research Needs Necessary to Implement an Alaska Climate Change Strategy
2017 https://accap.uaf.edu/sites/ default/files/resources/No me\%20Tribal\%20Climate \%20Adaptation \%20Plan\% 20\%28Final-

LowRes\%29.pdf

2011 http://www.nhjes.org/2011 US Army Corps of

Joint Conference/present Engineers (Federal ations/1B\%20Shoop\%20-

$\% 20 \mathrm{AK} \% 20$ training $\% 201 \mathrm{a}$ nds\%20v2[1].pdf

2011 http://fire.ak.blm.gov/cont ent/admin/awfcg_committ ees/Fire\%20Research\%20

Development\%20and\%20 Application/f.\%20Fire\%2

0Research\%20Topic\%20P romotion\%20Flyer_Final.

pdf

2010 https://www.fws.gov/nativ

eamerican/pdf/tek-

fisheries-resource-

monitoring-plan.pdf

Fisheries Resource

Monitoring

Committee

(Multiple

Organizations)

2017 https://adaptalaska.org/wp

content/uploads/2017/10/a

k-adaptation-

workshop.pdf

https://digital.library.unt.e du/ark:/67531/metadc2266 06/m2/1/high_res_d/rn_12 jun09_dftrpt.pdf Agency)

\section{Alaska Wildland \\ Fire Coordinating}

Organizations)

Aleutian Pribilof

Western Alaska

Landscape

Conservation

Cooperative,

Sea Landscape

Conservation

Cooperative

(Multiple

Organizations)

Alaska Research
Needs Work Group

(Multiple

Organizations)

\section{Unassigned Interview Western}

\section{Western}

Rural, Off-road

Assessment

Workshop

Multiple

Multiple

Presentation Expert Multiple Multiple

Knowledge

Multiple

Methods

Multiple

Multiple Islands Association,

Summary

Workshop

Arctic and Western

Rural, Off-road

Aleutian and Bering

Report

Expert Multiple Multiple 

National Climate Assessment Teams Addressing the

Impacts of Climate Change on Native Communities

\section{Southeast Alaska}

Environmental Conference:

Report on the Climate

Adaptation Summit

Snow, Ice and Permafrost

Hazards in Alaska

Southern Kenai Peninsula, Alaska Community Health Needs Assessment Executive summary

76 Stakeholder Based Regional Marine Research Plan for the Aleutian Islands

77 State of Change Climate Change Scenario Planning for Central Alaska Parks
2017 Not available

http://www.tribesandclima techange.org/project_docs Isubmission_to_nca_2011 _11_30.pdf

2016 https://nplcc.blob.core.win dows.net/media/Default/2

016 Documents/UAF/SE

\%20Climate\%20Adaptati

n\%20Summit_Final\%20R

eport-1.pdf

2011 https://accap.uaf.edu/sites/

default/files/resources/Ala $\underline{\text { skaCryosphereHazardFina }}$ l.pdf

\section{4 http://mappofskp.net/wp- content/uploads/2014/12/2 nd-CHNA-Exec-}

Summary.pdf

2016 https://seagrant.noaa.gov/ Portals/0/Documents/Abo

ut/AlaskaRegionalResearc

hPlan.pdf

2014 https://www.snap.uaf.edu/ sites/default/files/files/Sta e-ofChange Final_August2014.pdf
Environmental

Protection Agency

(Federal Agency)

Cooperative

Institute for

Research in

Environmental

Science (Research

Institute)

Central Council of Tlingit and Haida

ndian Tribes of

Alaska, Alaska

SeaGrant (Tribal

Government or

Organization)

Alaska Division of

Geological and

Geophysical

Surveys and Alaska

Center for Climate

Assessment and

Policy (Multiple

Organizations)

Southern Kenai

Mobilization

through Action and

Planning

Partnerships (Loca

Agencies)

Alaska SeaGrant

(Research Institute)

Report

National Park

Service, Scenarios

Report

and Arctic Planning,

Alaska Center for
Notes, lette

or other

Summary

Workshop

Southeast

Multiple

Assessment

Workshop Arctic

Rural, Off-road

Summary

Survey

Southcentra

Multiple

Workshop Western

Workshop

Interior an

Arctic

\section{Rural, On-road}

Rural, Off-road 
The State of Change: Climate Change Scenario Planning for Northwest Alaska Parks

tate of Change: Climate Change Scenario Planning for Southwest Alaska Parks

The Arctic Climate Chang and Security Policy

Conference

The effects of a changing climate on key habitats in Alaska

Tribal Recommendations for the Fiscal Year 2012

Department of the Interior Climate Change Adaptation Initiative

83 Tribal Science Priorities for the National EPA
2014 https://www snap.uaf.edu/ sites/default/files/files/Sta e-of-

Change Final_August2014.pdf

2014 https://www.snap.uaf.edu/ sites/default/files/files/Stat e-of-

Change_Final_August-

2014.pdf

2009 https://carnegieendowmen t.org/2009/06/24/arctic-

climate-change-and-

security-policy-

conference-final-report-

and-findings-pub-23314

2010 http://www.adfg.alaska.go $\mathrm{v} / \mathrm{static/lands/ecosystems/}$ pdfs/sp10_14.pdf

Alaska Department of Fish and Game

(State Agency)

2012 Not available

Affiliated Tribes of Northwest Indians

(Tribal Government

or Organization)

2011 http://www.epa.gov/tp/pdf /nts-priorities-guide-

2011.pdf

Tribal Science

Council (Tribal

Government or

Organization)

National Park

for Alaska

Planning,

Climate Assessment

Policy (Multiple

The Carnegie

nternational Peace
Rep

eport

Workshop Arctic and

Western

Rural, On-road

Workshop

Southcentral

Rural, Off-road

Report

Workshop Arctic

Rural, On-road

Summary Expert Multiple Rural, Off-road Knowledge

Notes, letters

or other

Expert

Knowledge

Multiple

Multiple

Needs

Expert

Knowledge
Multiple

Multiple 
US Climate Change Science

Program Stakeholder

Listening Session

85

Western Association of Fish and Wildlife Agencies

Climate Change Committee

Annual Update for Committee

Members

Whitefish and Other

Nonsalmon Fish Trends in

Lake Clark and Iliamna Lake,

Alaska, 2012 and 2013

Wildlife Response to

Environmental Arctic Change

\section{Not available}

2011

http://nrm.dfg.ca.gov/File
Handler.ashx?DocumentV
$\underline{\text { ersionID }=57780}$

ersionID $=57780$
2015 http://www.adfg.alaska.go v/techpap/TP411.pdf

https://archive.arcus.org/al
Alaska Department Report Workshop Multiple Multiple

of Environmental

Conservation (State

Agency)

\section{Western}

Adaptation

(Multiple

Organizations) of Fish and Game

and Bristol Bay

Native Corporation

(State Agency)

askafws/downloads/pdf/W

REACH_Workshop_Re (Federal Agency)
Association for Fish Assessment

and Wildlife

Agencies Climate

Committee

Alaska Department

US Fish and

Needs

Wildlife Service

Assessment
Workshop
Multiple

Multiple 
Appendix 2. Major sub-theme definitions that were used during the coding process.

\section{OBSERVATIONS and RESEARCH NEEDS}

\section{Wild Food Species:}

Species distribution: species distribution, dispersion, and migration patterns

Species abundance: population size, number of individuals per species,

Emerging species: novel or invasive species, new species in a certain area

Phenology: the timing of species on the landscape, changes to annual life cycle

Species health: wildlife/fish and plant disease, wildlife/fish body condition,

\section{Biophysical Environmental Conditions:}

Extreme weather: changing temperature, precipitation, and wind patterns

Fire regime: changes in wildfire severity, extent, and frequency

Hydrological conditions: lake/river drying, flooding, and morphology

Ice conditions: ocean/lake/river ice thickness, extent, and quality

Ocean acidification: oceanic $\mathrm{pH}$ levels

Permafrost: permafrost slumping, loss, and erosion

\section{Socio-economic Conditions:}

Relationships: individual and community-wide communication, connections, and relationships

Economic costs: financial costs associated with harvesting and processing wild foods

Food security: reliable access in terms of quantity, quality, and diversity of wild foods

Food safety: bioaccumalation, disease exposure

Travel access/safety: changes in travel conditions that impact harvester safety

\section{ADAPTATION STRATEGIES}

Training and education: classes, workshops, and outreach associated with wild food harvest

Legal and policy framework: new legal or decision-making processes and procedures that guide management of natural resources.

Management: Co-management, adaptive management, actionable, applied decision-making strategies for natural resource managers

Communication strategies: new virtual, written, or oral modes of communication to share wild food information

Food planning: household and community-wide wild foods sharing efforts 
Switching harvest species: adopting new techniques to harvest non-traditional or new wild foods

Food processing methods: adopting new techniques to process and store wild foods

Adapting season: adjusting the timing of wild food harvest

New travel methods: adopting new modes of transportation to access wild foods 